\title{
Occurrence of Crepidium aphyllum (King \& Pantl.) A.N. Rao (Orchidaceae) in Darjiling Hills: a new record for West Bengal, India
}

\author{
Lhamu Sherpa ${ }^{1}$, Norbu Sherpa ${ }^{1}$ and Nayan Thapa ${ }^{2}$ \\ ${ }^{1}$ Post Graduate Dept. of Botany, Darjeeling Government College, Darjeeling-734101, West Bengal, India \\ ${ }^{2}$ Communicating author: ATREE, Darjeeling Project Office, Darjeeling 734104, West Bengal, India \\ E-mails:1hamusherpa553@gmail.com;nssubunit@gmail.com; nayanthapa16@yahoo..com
} [Received 02.05.2018; Revised 09.06.2018; Accepted 10.06.2018; Published 30.06.2018]

\begin{abstract}
Collection of Crepidium aphyllum (King \& Pantl.) A.N. Rao (Orchidaceae) from temperate habitat of Labdah Khasmahal area of Darjeeling Hills is a new record of its occurrence for the state of West Bengal in India. A brief description and photographs have been provided for its easy identification.

Key words: Orchidaceae, Crepidium aphyllum, Microstylis, New record, Darjeeling, West Bengal
\end{abstract}

\section{INTRODUCTION}

The terrestrial orchid genus, Crepidium Blume, comprises of about 280 species, distributed mainly in the Asian tropics and subtropics, Australasia, and Indian Ocean islands, with a few species in temperate Asia (Chen \& Wood 2009) of which 10 species including two mycoheterotrophs are recorded so far from India (King \& Pantling 1898; Misra 2007; Jie et al. 2012). The genus was segregated from Malaxis Sol. ex Sw. by Szlachetko in 1995. The members of the genus are mostly terrestrial or sometimes lithophytic and characterized by small flowers, persistent floral bracts, column without foot and lip of flowers concave at base.

The District of Darjeeling in West Bengal state of India lies between $26^{\circ} 31^{\prime}$ to $27^{\circ}$ $13^{\prime} \mathrm{N}$ latitudes and between $87^{\circ} 59^{\prime}$ to $88^{\circ} 53^{\prime} \mathrm{E}$ longitudes spreading over an area of about $2436.55 \mathrm{~km}^{2}$ (O'Malley 1999). The altitudinal variation in various parts of the district ranges from $150 \mathrm{~m}$ (at Sukna) to $3660 \mathrm{~m}$ (at Sandakphu) with diverse topographical conditions (Das 1995, 2004).

During two field explorations to Labdah Khasmahal, Darjeeling in the months of July 2016 and August 2017, the authors could locate a few scattered small populations of a miniature orchid which was identified as Crepidium aphyllum (King \& Pantl.) A.N. Rao with the help of available published literature [King \& Pantling (1898), Rao (1988, 2000), Tang \& Wang (1951), Matthew (1981), Banerji (1982), Jie et al. (2012), Yonzone et al. (2012) and Swami (2016)]. A few plant samples were collected and processed into mounted herbarium specimens following Jain \& Rao (1977) and deposited in the herbaria of Llyod's Botanic Garden and Botany Department, Darjeeling Government College, Darjeeling. In India Crepidium aphyllum is reported so far only from Sikkim (King \& 
Pantling 1898) and Aruanchal Pradesh (Hegde \& Rao 1987). hence the present collection of this species from Darjeeling Hills forms a new distributional record for this region as well as for the state of West Bengal. A brief description of the species along with photographs is provided here for its easy identification.
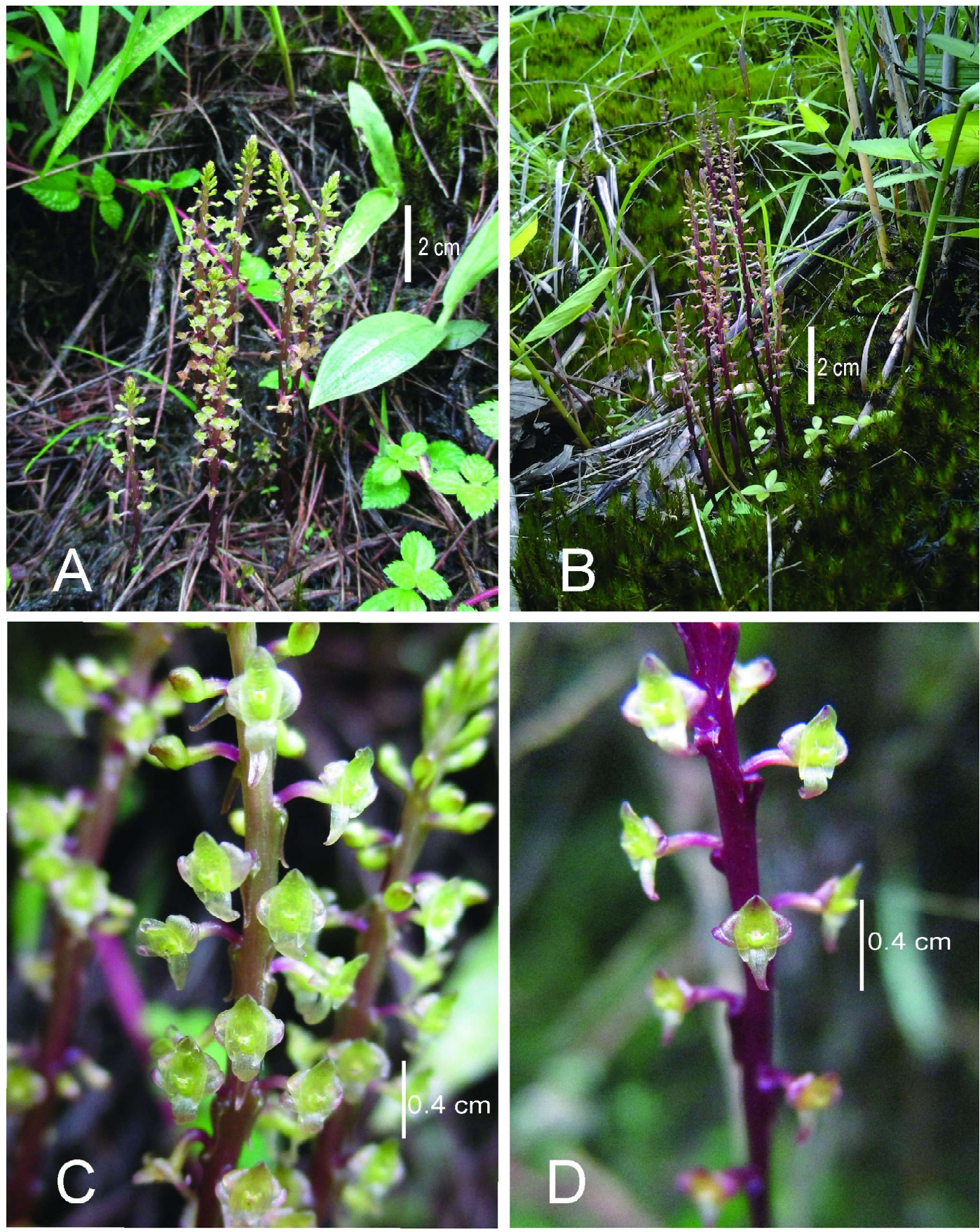

Figure 1. Crepidium aphyllum (King \& Pantl.) A.N. Rao. A\&B. Plants in natural habitat; C. Flower scapes; D. Portion of an inflorescence showing closer view of flowers. 
Crepidium aphyllum (King \& Pantl.) A.N. Rao in J. Orc. Soc. India 14: 65. 2000; Microstylis aphylla King \& Pantl., Ann. Roy. Bot. Gard. (Calcutta) 8: 18. 1898; Malaxis aphylla (King \& Pantl.) Tang \& F.T. Wang, in Acta Phytotax. Sin. 1: 71. 1951; S.N.Hegde \& A.N.Rao in Ind. J. For. 10(3): 197.1987; A.N.Rao in J. Orch. Soc. India 2:17. 1988; Jie, Xiao-hua \& Wei-tao in J. Trop. Subtrop. Bot. 20(3):239. 2012.

Type: India, Sikkim, Valley of Teesta, R. Pantling, 455 (K!). [http://specimens.kew.org/ herbarium/K000387669]. [Figure 1].

A small mycoheterotrophic herb, $10-25 \mathrm{~cm}$ long, fragile; Tuber solitary, oblong, spindle shaped, hairy, roots zero or few at the base of the scape; Scape $5-12 \mathrm{~cm}$ long, erect, internodes $2-5$, with $2-5$ tubular sheaths, glabrous, yellowish-purple; Inflorescence terminal, erect, $2-10 \mathrm{~cm}$ long, $10-40$ flowered raceme, narrowing and dense above; Floral bracts lanceolate, deflexed, $1 \mathrm{~mm}$ broad and $3 \mathrm{~mm}$ long, shorter than pedicel in basal flowers and exceeding pedicel in upper younger flowers, margin entire, apex acute, yellowish-purplegreen in color, glabrous, persistent; Flowers $2-3.5 \mathrm{~mm}$ broad and 3-5 mm long, nonresupinate, yellow flushed with dull purple, glabrous; pedicel $2-3 \mathrm{~mm}$ long (including ovary), glabrous; lateral sepals ovate, $1.2-1.4 \mathrm{~mm}$ broad and $1.4-1.5 \mathrm{~mm}$ long, recurved, apex obtuse, margin entire, dorsal sepal elliptic, $1 \mathrm{~mm}$ broad and $1.7-2 \mathrm{~mm}$ long, apex obtuse, margin entire, revolute, lateral petals linear, $0.3 \mathrm{~mm}$ broad and $1.6-2 \mathrm{~mm}$ long, apex subacute, recurved, margin entire, adpressed to lateral sepals, Lip ovate, $1.2-2 \mathrm{~mm}$ broad and $2-2.5(-3) \mathrm{mm}$ long, apex obtuse, narrowed in the middle with two sagittate auricles at the base, auricles lanceolate-triangular, $0.5 \mathrm{~mm}$ broad and $1 \mathrm{~mm}$ long, apex sub-acute, column ca. $1 \mathrm{~mm}$ long, apically lobed with a bow-shaped structure, anther cap elliptic, pollinia 4; Capsules oblong-obovoid, 3 - $4 \mathrm{~mm}$ long.

Exsiccates: West Bengal: Darjeeling, Labdah Khasmahal, 26 $57^{\prime} 49.45^{\prime \prime} \mathrm{N}$ and $88^{\circ} 20^{\prime}$ 29.77" E, 1606 $\pm 10 \mathrm{~m}, 10.07 .2016$, Norbu Sherpa \& Nayan Thapa, 00210 (DGCH); Labdah Khasmahal, 26 57' 51.96" N and 88 20' 60.37" E, 1618 $\pm 10 \mathrm{~m}, 13.08 .2017$, Lhamu Sherpa \& Norbu Sherpa, LB014381 (LBH).

Specimen Examined: Images: Sikkim: Valley of Teesta, 305.0 m, 11.07.1896, R. Pantling, 455 (K000387669!); Valley of Teesta, 300 m, 11.07.1896, R. Pantling, 455 (G000354757!).

Local Distribution: Labdah Khasmahal, Darjeeling, West Bengal.

Global Distribution: India (Arunachal Pradesh, Sikkim, West Bengal), China.

\section{Acknowledgements}

Authors are grateful to the unknown reviewers of this paper for their critical observations and useful suggestions. They are also thankful to Manoj Kumar Chhetri, Range Officer of Lloyd Botanic Garden and to Dr. Archan Bhattacharya, Head of Department of Botany, Darjeeling Government College for offering all the working facilities.

\section{LITERATURE CITED}

Banerji, M.L. 1982. Orchids of Nepal. Bishen Singh Mahendra Pal Singh, Dehra Dun, India.

Chen, S.C. \& Wood, J.J. 2009. Crepidium Blume. In: Chen, S.C., Liu. Z.J., Zhu. G.H. et al. Flora of China Vol. 25. Beijing: Sciences Press, St. Louis: Missouri Botanical Garden Press, pp. $229-234$. 
Das, A.P. 1995. Diversity of the angiospermic flora of Darjeeling Hills. In: A.K. Pandey (ed.), Taxonomy and Biodiversity, CBS, New Delhi, pp118 - 127,

Das, A.P. 2004. Floristic studies in Darjiling hills. Bull. Bot. Surv. India 46(1-4): 1 - 18.

Hegde, S.N. \& Rao, A.N. 1987. Further contributions to the Orchid flora of Arunachal Pradesh, India-3. Ind. J. For. 10(3): $191-198$.

http://specimens.kew.org/herbarium/K000387669

Jain, S.K., \& Rao, R.R. 1977. Field and Herbarium methods. Today and Tomorrow's Printers and Publisher, New Delhi.

Jie, F.; Jin, X. \& Jin, W. 2012. Two new records of Orchidaceae from China. J. Trop. Subtrop. Bot. 20(3): $239-242$.

King, G. \& Pantling, R. 1898. The Orchids of Sikkim Himalaya. Ann. Roy. Bot. Gard. (Calcutta) 8: $1-342$ \& Pl. 1 - 144.

Matthew, K.M., 1981. An enumeration of the flowering plants of Kurseong, Darjeeling District, West Bengal, India. Bishen Singh Mahendra Pal Singh, Dehra Dun, India, pp110.

Misra, S. 2007. Orchids of India. Bishen Singh Mahendra Pal Singh, Dehradun, Pp. 279 230.

O’Malley, L.S.S. 1907. (Repr. 1999). Bengal District Gazetteers Darjiling. Logos Press, New Delhi, India.

Rao, A.N. 2000. Notes on some new additions and nomenclatural changes in two orchids of Arunachal Pradesh. J. Orch. Soc. India. 14: 61 - 66.

Rao, A.N. 1988. A taxonomic review of the saprophytic orchids of Arunachal Pradesh, India. J. Orch. Soc. India. 2(1,2): 9 - 17.

Swami, N. 2016. Terrestrial Orchids. ATREE Publisher, Bangalore. ISBN 978-93-5258$377-5$.

Szlachetko, D.L. 1995. Systema Orchidalium. Fragmenta Floristica et Geobotanica, Supplement 3: 123-133.

Tang, T. \& Wang. F.T. 1951. Contributions to the knowledge of Eastern Asiatic Orchidaceae II. Acta Phytotax. Sinica. 1: 71.

Yonzone, R.; Lama, D.; Bhujel, R.B.; Gogoi, K.\& Rai, S. 2012. Taxonomic assessment on the reported orchid species of Darjeeling district from flora of Bhutan, the Orchids of Bhutan - A review. Intn. J. Pharm. Life Sci. 3(4): 1590 - 606. 